\title{
T-cell Subset Regulation in Atopy
}

\author{
Marek Jutel • Cezmi A. Akdis
}

Published online: 27 January 2011

(C) The Author(s) 2011. This article is published with open access at Springerlink.com

\begin{abstract}
Presentation of processed allergen by antigenpresenting cells to T-helper (Th) lymphocytes, which is influenced costimulatory signals, cytokines, chemokines, and regulatory $\mathrm{T}$ cells (Tregs), determines the development of different types of T-cell immunity. The discovery of Tregs revolutionized the primary concepts of immune regulation interpreted within the framework of a binary Th1/Th2 paradigm. Tregs play a central role in the maintenance of peripheral homeostasis, the establishment of controlled immune responses, and the inhibition of allergen-specific effector cells. Recently, some other T-cell subsets appeared, including Th17 and Th9 cells, which control local tissue inflammation through upregulation of proinflammatory cytokines and chemokines. This review aims to discuss our understanding of the T-cell subset reciprocal interaction in atopy.
\end{abstract}

Keywords Atopy $\cdot \mathrm{T}$ cells $\cdot$ Tolerance

\section{Introduction}

The activity of $\mathrm{T}$ lymphocytes is largely dependent on specialized introduction of antigenic materials by highly specialized antigen-presenting cells [1]. Thus, dendritic

\footnotetext{
M. Jutel $(\bowtie)$

Department of Clinical Immunology,

Wroclaw Medical University,

T. Chalubinskiego 5,

50-368, Wroclaw, Poland

e-mail: mjutel@ak.am.wroc.pl

C. A. Akdis

Swiss Institute of Allergy and Asthma Research,

Davos, Switzerland

e-mail: akdisac@siaf.uzh.ch
}

cells (DCs) are essential for the differentiation of naïve $\mathrm{T}$ cells into T-helper (Th)1, Th2, Th9, Th17, and Th22 effector T-cell subsets [2] via release of cytokines and other cofactors (Fig. 1). The differentiation of naïve T cells into Th2 cells is induced in the presence of interleukin (IL)4. Allergen-specific Th2 cells acting through the effects of released IL-4 and IL-13 induce immunoglobulin class switching to $\operatorname{IgE}$ and clonal expansion of naive and IgEpositive memory B cells. Cross-linking of IgE bound to FceRI (high-affinity receptor for IgE) on the effector mast cells and basophils results in the release of vasoactive amines (including histamine); lipid mediators (eg, prostaglandin $\mathrm{D}$, platelet-activating factor, leukotriene [LT] $\mathrm{C}_{4}$, $\mathrm{LTD}_{4}$, and $\mathrm{LTE}_{4}$ ); chemokines (CXC-chemokine ligand 8 [CXCL8], CXCL10, CC-chemokine ligand 2 [CCL2], CCL4, and CCL5); and cytokines such as IL-4, IL-5, and IL-13, leading to the development of type 1 immediate hypersensitivity reaction [3]. Then, after 6 to $12 \mathrm{~h}$, should a late-phase allergic reaction occur, it appears due to the migration of allergen-specific $\mathrm{T}$ cells, which are reactivated and clonally expand under the influence of chemokines and other cytokines at the site of allergen exposure. The major effector cells are eosinophils; however, Th1 cells, mast cells, and basophils also contribute at this phase [3]. The cellular chronic late-phase response, which is mostly driven by allergen-specific $\mathrm{T}$ cells activated by continuous allergen exposure, is the driving force for the persistent inflammation and/or tissue remodeling responsible for the chronic symptoms of allergic disease [4].

\section{Effector T-cell Subsets}

Naive T lymphocytes are primed by DCs that mature and migrate from peripheral tissues to the T-cell areas of 


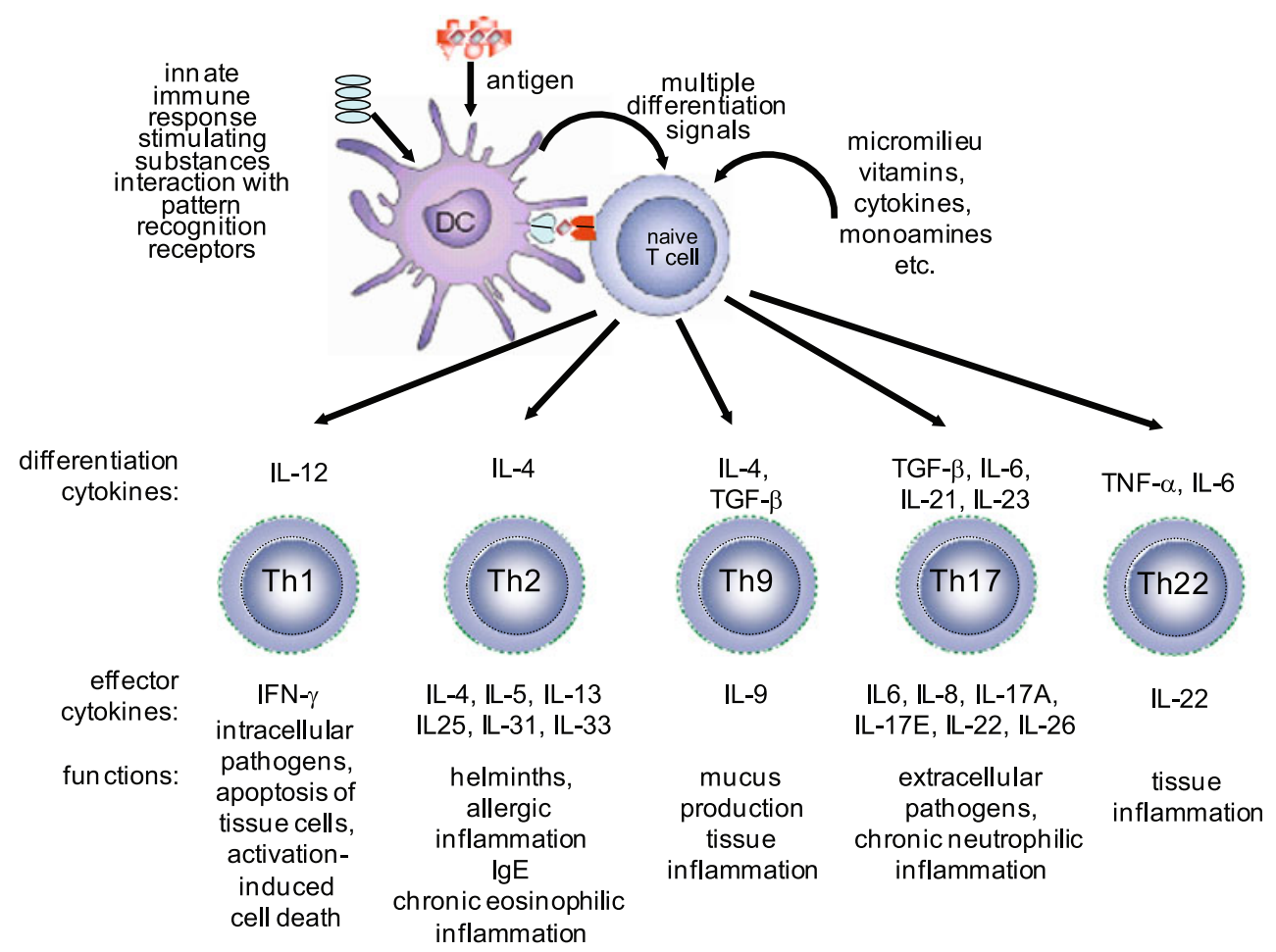

Fig. 1 The differentiation of naïve $\mathrm{T}$ cells. Depending on the adjuvanticity of the substances co-exposed with the antigen and status of the cells and cytokines in the microenvironment, naïve $T$ cells can differentiate into T-helper (Th)1, Th2, Th9, Th17, and Th22 types of T cells. Based on their respective cytokine profiles, responses to

chemokines, and interactions with other cells, these T-cell subsets can promote different types of inflammatory responses. IFN interferon, $I L$ interleukin, $T G F$ transforming growth factor, $T N F$ tumor necrosis factor

secondary lymphoid organs, where they produce regulatory cytokines [5]. Two distinct subsets of DCs have been described in humans. Myeloid DCs (mDCs) [6] express Toll-like receptor (TLR2) through TLR6 and TLR8 and produce IL-12 in response to the bacterial and viral stimuli. Plasmocytoid DCs (pDCs) express TLR7 and TLR9 and release large quantities of type 1 interferons during the outcome of antiviral immune responses [5, 7-9]. pDCs directly suppress the ability of mDCs to generate effector $\mathrm{T}$ cells [10]. pDCs are capable of stimulating the development of regulatory $\mathrm{T}$ cells (Tregs), probably via the inducible costimulatory molecule (ICOS) ligand-dependent pathway $[8,10]$. It has been shown that the depletion of pDCs in the lungs results in lack of tolerance to inhaled antigens [10, 11]. The other two DC populations that are present at inflammatory sites of the skin in atopic dermatitis are the classical Langerhans cells and the inflammatory dendritic epidermal cells [12]. It has been recognized that inflammatory dendritic epidermal cells activate the Th1-cell subset. Classical Langerhans cells induce the Th2-cell subset [13]. Furthermore, the expression of IgE FcERI on the surface of DCs and Langerhans cells is not specific to atopic eczema but rather determined by the type of inflammatory status in various inflammatory skin diseases. [14].
It has been demonstrated that stem cell factor, the ligand for c-kit, which is a receptor tyrosine kinase type III, affects the synthesis of IL-6 and Jagged-2, the ligand of Notch. Engagement of Notch on the T cells with Jagged on DCs and T-cell receptors with major histocompatibility complex-IIcoupled peptide induces priming of Th cells [15]. Thus, Notch affects the Th-cell differentiation by promoting the Th2 and Th17 development but shows no effect on Th1 response [16]. Apoptosis-resistant DCs effectively generate antigen-specific Th2 cells in vitro and in vivo and induce $\operatorname{IgE}$ responses in vivo independent of the sensitization status of the host [17].

\section{Th1 and Th2 Cells}

The subsets of $\mathrm{CD}^{+}$Th lymphocytes are categorized on the basis of their distinct cellular functions and cytokine secretion capacities [18]. Originally, two subsets-Th1 and Th2 lymphocytes - were described, which accounted for a binary Th1/Th2 paradigm. Since this time, new Th subsets have been recognized as important players in immune regulation. They include well-characterized Tregs as well as newly described proinflammatory Th17 or Th9 cell lineages. In the near future, it is likely that new Th subsets will be described and characterized. The imbalance between 
various T-cell subsets accounts for different immune pathologies, including atopy.

Peripheral T-cell clones differentiate into these subsets using self-reinforcing transcriptional circuitries that involve major transcriptional regulators: T-box expressed in T cells (Tbet) in Th1 cells, trans-acting T-cell-specific transcription factor (GATA-3) in Th2 cells, forkhead box P3 (FoxP3) in Tregs, and retinoid-related orphan receptor (ROR) $\gamma \mathrm{t} / \mathrm{ROR} \alpha$ in Th17 cells. It has been recognized that the counterregulation between the T-cell effector subsets is crucial in immune regulation and in maintaining the balance between different types of the immune response [19-22]. Thus, the activation of Tbet inhibits both Th2 cell-mediated eosinophil recruitment and Th17 cell-mediated neutrophil recruitment into the airways [23]. An association between a specific Tbet haplotype and allergic asthma in children has been suggested [24].

Th2 cells predominantly mediate $\operatorname{IgE}$ responses and allergic inflammation and are also involved in immunity to parasites $[3,25]$. There are likely to be several mechanisms of $\mathrm{Th} 2$ profile dominance in atopic disease. It has been postulated that Th1 cells are prone to activation and apoptosis, as their high IFN- $\gamma$-producing fraction and $\mathrm{CXCR}^{+} \mathrm{T}$ cells in particular show increased apoptosis in atopic individuals [26]. Th1 cells are involved in cellmediated defense against intracellular microorganisms and in promotion of memory $\operatorname{IgG}$ responses. Their phenotype is dominated by IL-2, IFN- $\gamma$, and tumor necrosis factor- $\beta$ cytokine profiles. Th1 cells differentiate after stimulation with IL-12, IL-18, and IL-17. It must be emphasized that Th1 cells also engage in the effector mechanisms of allergic disease. It has been recognized that they induce apoptosis of keratinocytes in atopic dermatitis. In asthma, these cells induce apoptosis of epithelium and bronchial smooth muscle cells $[27,28]$.

The phenotype of Th2 cells is characterized by secretion of proinflammatory cytokines IL-4, IL-5, and IL-13, which are clustered on chromosome $5 \mathrm{q}$ in close proximity with granulocyte-macrophage colony-stimulating factor. These cytokines are associated with pathogenesis of $\operatorname{IgE}$ and eosinophilia. Th2 polarizing factors include monocytic chemotactic protein 1 and OX40 ligand [29]. OX40 ligation upregulates IL-4 production, which in turn promotes Th2 polarization [29]. Thymic stromal lymphopoietin (TSLP) is a novel growth factor produced by epithelial cells that promotes the proliferation and differentiation of committed B-cell progenitors. It can substitute for the activity of IL-7, the B-cell growth and maturation factor. TSLP plays an essential role in allergic inflammation at the epithelial cell and DC interface [30] and activates human $\mathrm{mDC}$ s to induce inflammatory Th2 responses [31]. TSLP levels are increased in asthma [32]. TSLP-induced DCs mature and migrate into the draining lymph nodes and trigger the adaptive phase of allergic immune response. TSLP induces OX40L expression in DCs, which induce the differentiation of allergen-specific naive $\mathrm{CD} 4^{+} \mathrm{T}$ cells to inflammatory Th2 cells [33].

Recently, IL-25 (IL-17E), a member of the IL-17 family of immunoregulatory cytokines, was shown to regulate Th2-type immunity. Blocking of IL-25 in an experimental model of allergic asthma prevented airway hyperresponsiveness and suppressed IL-5 and IL-13 synthesis, as well as eosinophil infiltration, goblet cell hyperplasia, and serum $\operatorname{IgE}$ secretion [34].

\section{Regulatory T Cells}

The discovery of Tregs contributed tremendously to the understanding of the mechanisms of peripheral tolerance and induction of Th1 or Th2 immunity [35]. Tregs are characterized by their IL-10 and transforming growth factor (TGF)- $\beta$ secretion capacities [36]. Tregs suppress allergeninduced specific T-cell activation. They also suppress effector cells of allergic inflammation such as mast cells, basophils, and eosinophils $[37,38]$ as well $\operatorname{IgE}$ production [38-40]. Notably, Treg-derived cytokines IL-10 and TGF- $\beta$ induce synthesis of noninflammatory $\mathrm{IgG}_{4}$ and $\operatorname{IgA}$ isotypes, respectively [37]. Several subsets of Tregs showing distinct phenotypes and regulatory effects have been recognized. They include the naturally occurring, thymus-selected $\mathrm{CD} 4{ }^{+} \mathrm{CD} 25^{+} \mathrm{FoxP}^{+}$Tregs and the inducible type 1, IL-10-secreting Tregs [41]. Furthermore, regulatory subsets of $\mathrm{CD}^{+} \mathrm{T}$ cells, $\gamma \delta \mathrm{T}$ cells, DCs, IL10-producing $\mathrm{B}$ cells, natural killer cells, and resident tissue cells, which may promote the generation of $\mathrm{CD} 4^{+}$ Tregs, have been described [42].

The mechanisms by which Tregs induce peripheral tolerance to allergens may go beyond the effects of cytokines produced by these cells. They may directly interact with DCs and compete with naïve $\mathrm{T}$ cells in a physical manner by creating aggregates around DCs and in this way inhibit their maturation [43]. In addition, Tregs downregulate the expression of CD80/CD86 on DCs [43]. Naturally occurring Tregs express high cytotoxic Tlymphocyte antigen-4 (CTLA-4). CTLA-4 is a CD28 family member that binds CD80/CD86. However, it does so with a higher affinity than CD28. In contrast to stimulatory effects of CD28, CTLA-4 inhibits T-cell activation [44-46].

Regarding other IL-10-producing cells (eg, monocytes), compared with healthy controls, their percentage has been shown to be significantly increased in atopic patients [47]. They preferentially differentiate into SOCS3-expressing, alternatively activated macrophages, which induce Th2 immune response [47]. The physiologic relevance of this phenomenon is unclear. IL-10-treated DCs potently sup- 
press the airway inflammation and hypersensitivity as well as Th2 cytokine production. These effects are exerted through endogenous production of IL-10 [48]. At the molecular level, IL-10 inhibits CD28 and ICOS costimulations of T cells via Src homology 2 domain-containing protein tyrosine phosphatase (SHP)-1 [49]. IL-10 receptor-associated tyrosine kinase (Tyk) 2 acts as a constitutive reservoir for SHP-1 in resting T cells. Tyrosine phosphorylates SHP-1 upon IL-10 binding. SHP-1 rapidly binds to CD28 and ICOS costimulatory receptors and dephosphorylates them within minutes. Binding of phosphatidylinositol-3-kinase to either costimulatory receptor is inhibited, and downstream signaling is consequently blocked. In an experimental model, spleen cells from SHP-1-deficient mice showed increased proliferation with CD28 and ICOS stimulation in comparison with wildtype mice, in which cells were not suppressed by IL-10. It has been postulated that the inhibition of the CD28 or ICOS costimulatory pathways by SHP-1 may provide a novel approach for direct T-cell suppression [49]. Src homology 2 domain-containing inositol 5-phosphatase 1 has been shown consistently to inhibit allergic reactions as a negative regulator of cytokine and immune receptor signaling. On the contrary, its deficiency leads to spontaneous development of allergic-like inflammation in the murine lung [50].

TGF- $\beta$ is another key player in immune tolerance. It exerts its activity in the intestinal mucosa and can induce immune tolerance to dietary antigens [51]. BALB/c mice treated orally with ovalbumin (OVA) and TGF- $\beta$ showed augmented reduction of OVA-specific $\operatorname{IgE}$ and $\operatorname{IgG}_{1}$ antibodies, T-cell reactivity, and immediate-type skin reactions when compared with mice treated orally with OVA alone [51]. Thus, local administration of TGF- $\beta$ may become a strategy to prevent and treat allergic diseases.

Tregs can directly inhibit the effector cells of allergic inflammation [52]. Tregs directly inhibit the FceRIdependent mast cell degranulation through cell-cell contact involving OX40-OX40 ligand interactions [53]. The depletion or inactivation of Tregs causes enhancement of the anaphylactic response $[2,53]$. IL-10 regulates mast cell maintenance and proliferation in peripheral tissues [54] and reduces proinflammatory cytokine release from mast cells [55]. IL-10 also inhibits eosinophil activities [56].

IL-10 is a potent suppressor of allergen-specific $\operatorname{IgE}$, whereas it induces $\mathrm{IgG}_{4}$ production [37]. IL-10 decreases $\varepsilon$ transcript expression, thus downregulating IgE production, while enhancing $\gamma 4$ transcript expression and increasing $\mathrm{IgG}_{4}$ production [57]. Supporting evidence has been provided by studies on Treg-B-cell interaction through glucocorticoid-induced TNFR-related protein (GITR)/GITR ligand [58]. The induction of $\mathrm{IgG}_{4}$ and suppression of $\operatorname{IgE}$ in healthy individuals shows the direct influence of Tregs on B cells [39].
During allergen-specific immunotherapy, the development of peripheral T-cell tolerance is characterized mainly by the generation of allergen-specific Tregs, which suppress proliferative and cytokine responses against the major allergens [37, 38, 59-67]. Moreover, local FoxP $3^{+} \mathrm{CD} 25^{+}$ $\mathrm{T}$ cells in the nasal mucosa and their increased numbers after immunotherapy were demonstrated [68]. Treg-derived IL-10 not only generates tolerance in $\mathrm{T}$ cells but also regulates specific isotype formation and skews the specific response from an IgE to an $\mathrm{IgG}_{4}$-dominated phenotype [38]. IL-10 is a potent suppressor of total and allergen-specific IgE, while it simultaneously increases $\operatorname{IgG}_{4}$ production. During allergenspecific immunotherapy, increases in allergen-specific $\operatorname{IgG}_{4}$ and $\mathrm{IgG}_{1}$, with 10 - to 100 -fold increases in their serum levels, were observed $[69,70]$.

\section{Th17 Cells}

Th17 cells have been shown to induce host protection against extracellular pathogens and tissue inflammation [20, 71, 72]. Differentiation of Th17 (IL-17A- and IL-17 Fproducing) cells is induced by IL-6, IL-21, IL-23, and TGF$\beta$ [2]. Th17 cells have been implicated in the pathogenesis of autoimmune diseases [73]. They are characterized by a strong IL-17-producing capacity. IL-17 family cytokines include IL-17A through F, which control inflammatory responses in the tissue by triggering secretion of proinflammatory cytokines and chemokines [71, 74]. Tregs can suppress Th17 cells and autoimmunity. Activation of Th17 cells can start tissue inflammation [75]. IL-17 has been shown to coordinate granulocyte influx in allergic airway inflammation models [76, 77]. A member of the IL-17 family, IL-17 F (IL-25), is designated to the Th2-type group. It promotes Th2-type response; induces eosinophil$\mathrm{ia}$; increases serum $\operatorname{IgE}$ and $\mathrm{IgG}_{1}$; and upregulates tissue expression of IL-4, IL-5, and IL-13 [78-80].

\section{Th9 and Th22 Cells}

Th9 represents a novel, distinct population of effector Thelper cells involved in tissue inflammation [2]. It shows no suppressive functions. This population is characterized by IL-9 and IL-10 secretion. These cells differentiate from naïve cells after IL- 4 and TGF- $\beta$ stimulation. It has been shown that IL-9 together with TGF- $\beta$ can contribute to Th17 cell differentiation, and Th17 cells themselves can produce IL-9 [81]. Th9 cells have been shown to induce tissue inflammation In autoimmune diseases, however, the role of this T-cell subset in allergic responses remains to be elucidated. Another novel T-cell subset has been demonstrated in T cells that independently express IL-22 with low expression levels of IL-17 and play a role in atopic dermatitis. IL-22 can be protective in animal models of 
colitis, partially attributable to the induction of epithelial wound healing and mucus production. Although IL-22 was originally described as a cytokine produced by Th17 cells, it is now recognized that IL-22 expression by Th cells can be induced independently of IL-17 expression. Therefore, regulation of the production of IL-22 could be a potent avenue for influencing the course of inflammatory epithelial diseases [82].

\section{Conclusions}

Many factors contribute to development of the Th2 profile in atopic individuals. Th2-derived IL-4 and IL-13 exert an important role in class switching in B lymphocytes that results in IgE production. Recent evidence on T-cell subset reciprocal regulation and counterbalance between Th1 and Th2 cells to Th17 and Tregs has greatly influenced our understanding of immunoregulation and peripheral tolerance. Different types of Tregs control several facets of allergic inflammation. They regulate $\mathrm{IgE}$ versus $\mathrm{IgG}_{4}$ and drive the allergen-specific antibodies toward the noninflammatory and nonanaphylactic phenotype. They also directly or indirectly inhibit effector cells and consequently restrict allergic inflammation. The understanding of these insights into the mechanisms of immunoregulation leads to novel therapeutic approaches.

Acknowledgments The authors' laboratories are supported by the Swiss National Science Foundation grants 32-112306 and 32-118226, the Christine Kühne Center for Allergy Research and Education (CKCARE), and the KGHM Foundation-Polska Miedz. Dr. Akdis has also received support from the Global Allergy and Asthma European Network.

Disclosure Dr. Akdis has received research support from Novartis and Stallergenes and has provided legal consultation services/expert witness testimony for Actelion Pharmaceuticals, Aventis, and Allergopharma. Dr. Jutel reported no potential conflicts of interest relevant to this article.

Open Access This article is distributed under the terms of the Creative Commons Attribution Noncommercial License which permits any noncommercial use, distribution, and reproduction in any medium, provided the original author(s) and source are credited.

\section{References}

1. Goldberg AL, Rock KL, Proteolysis, proteasomes and antigen presentation. Nature 1992;357: 375-379.

2. Akdis CA, Akdis M, Mechanisms and treatment of allergic disease in the big picture of regulatory $\mathrm{T}$ cells. J Allergy Clin Immunol 2009;123: 735-746; quiz 747-738.

3. Larche M, Akdis CA, Valenta R, Immunological mechanisms of allergen-specific immunotherapy. Nat Rev Immunol 2006;6: 761771.
4. Kay AB, Asthma and inflammation. J Allergy Clin Immunol 1991;87: 893-910.

5. Jarrossay D, Napolitani G, Colonna M, Sallusto F, Lanzavecchia A, Specialization and complementarity in microbial molecule recognition by human myeloid and plasmacytoid dendritic cells. Eur J Immunol 2001;31: 3388-3393.

6. Rissoan MC, Soumelis V, Kadowaki N, Grouard G, Briere F, de Waal Malefyt R, Liu YJ, Reciprocal control of T helper cell and dendritic cell differentiation. Science 1999;283: 1183-1186

7. Ito T, Kanzler H, Duramad O, Cao W, Liu YJ, Specialization, kinetics, and repertoire of type 1 interferon responses by human plasmacytoid predendritic cells. Blood 2006;107: 2423-2431.

8. Ito T, Yang M, Wang YH, Lande R, Gregorio J, Perng OA, Qin XF, Liu YJ, Gilliet M, Plasmacytoid dendritic cells prime IL-10producing $\mathrm{T}$ regulatory cells by inducible costimulator ligand. $\mathrm{J}$ Exp Med 2007;204: 105-115.

9. Kadowaki N, Ho S, Antonenko S, Malefyt RW, Kastelein RA, Bazan F, Liu YJ, Subsets of human dendritic cell precursors express different Toll-like receptors and respond to different microbial antigens. J Exp Med 2001;194: 863-869.

10. de Heer HJ, Hammad H, Soullie T, Hijdra D, Vos N, Willart MA, Hoogsteden HC, Lambrecht BN, Essential role of lung plasmacytoid dendritic cells in preventing asthmatic reactions to harmless inhaled antigen. J Exp Med 2004;200: 89-98.

11. Kool M, Lambrecht BN, Dendritic cells in asthma and COPD: opportunities for drug development. Curr Opin Immunol 2007;19: 701-710.

12. Wollenberg A, Kraft S, Hanau D, Bieber T, Immunomorphological and ultrastructural characterization of Langerhans cells and a novel, inflammatory dendritic epidermal cell (IDEC) population in lesional skin of atopic eczema. J Invest Dermatol 1996;106: 446453.

13. Novak N, Bieber T, The role of dendritic cell subtypes in the pathophysiology of atopic dermatitis. J Am Acad Dermatol 2005;53: S171-176.

14. Bieber T, Braun-Falco O, IgE-bearing Langerhans cells are not specific to atopic eczema but are found in inflammatory skin diseases. J Am Acad Dermatol 1991;24: 658-659.

15. Galli SJ, Tsai M, Piliponsky AM, The development of allergic inflammation. Nature 2008;454: 445-454.

16. Ray P, Krishnamoorthy N, Ray A, Emerging functions of c-kit and its ligand stem cell factor in dendritic cells: regulators of $\mathrm{T}$ cell differentiation. Cell Cycle 2008;7: 2826-2832.

17. Arques JL, Regoli M, Bertelli E, Nicoletti C, Persistence of apoptosis-resistant $\mathrm{T}$ cell-activating dendritic cells promotes $\mathrm{T}$ helper type- 2 response and $\operatorname{IgE}$ antibody production. Mol Immunol 2008;45: 2177-2186.

18. Mosmann TR, Cherwinski H, Bond MW, Giedlin MA, Coffman RL, Two types of murine helper $\mathrm{T}$ cell clone. I. Definition according to profiles of lymphokine activities and secreted proteins. J Immunol 1986;136: 2348-2357.

19. Wells JW, Cowled CJ, Giorgini A, Kemeny DM, Noble A, Regulation of allergic airway inflammation by class I-restricted allergen presentation and CD8 T-cell infiltration. J Allergy Clin Immunol 2007;119: 226-234.

20. Schmidt-Weber CB, Akdis M, Akdis CA, TH17 cells in the big picture of immunology. J Allergy Clin Immunol 2007;120: 247-254.

21. Romagnani S, Coming back to a missing immune deviation as the main explanatory mechanism for the hygiene hypothesis. J Allergy Clin Immunol 2007;119: 1511-1513.

22. Chatila TA, Li N, Garcia-Lloret M, Kim HJ, Nel AE, T-cell effector pathways in allergic diseases: transcriptional mechanisms and therapeutic targets. J Allergy Clin Immunol 2008;121: 812823; quiz 824-815.

23. Fujiwara M, Hirose K, Kagami S, Takatori H, Wakashin H, Tamachi T, Watanabe N, Saito Y, Iwamoto I, Nakajima H, T-bet 
inhibits both Th2 cell-mediated eosinophil recruitment and Th17 cell-mediated neutrophil recruitment into the airways. J Allergy Clin Immunol 2007;119: 662-670.

24. Munthe-Kaas MC, Carlsen KH, Haland G, Devulapalli CS, Gervin K, Egeland T, Carlsen KL, Undlien D, T cell-specific Tbox transcription factor haplotype is associated with allergic asthma in children. J Allergy Clin Immunol 2008;121: 51-56.

25. Romagnani S, Regulation of the T cell response. Clin Exp Allergy 2006;36: 1357-1366.

26. Akkoc T, de Koning PJ, Ruckert B, Barlan I, Akdis M, Akdis CA, Increased activation-induced cell death of high IFN-gammaproducing $\mathrm{T}(\mathrm{H}) 1$ cells as a mechanism of $\mathrm{T}(\mathrm{H}) 2$ predominance in atopic diseases. J Allergy Clin Immunol 2008;121: 652-658 e651.

27. Trautmann A, Akdis M, Kleemann D, Altznauer F, Simon HU, Graeve T, Noll M, Brocker EB, Blaser K, Akdis CA, T cellmediated Fas-induced keratinocyte apoptosis plays a key pathogenetic role in eczematous dermatitis. J Clin Invest 2000;106: 2535 .

28. Trautmann A, Schmid-Grendelmeier P, Kruger K, Crameri R, Akdis M, Akkaya A, Brocker EB, Blaser K, Akdis CA, T cells and eosinophils cooperate in the induction of bronchial epithelial cell apoptosis in asthma. J Allergy Clin Immunol 2002;109: 329337.

29. Ohshima Y, Yang LP, Uchiyama T, Tanaka Y, Baum P, Sergerie M, Hermann P, Delespesse G, OX40 costimulation enhances interleukin-4 (IL-4) expression at priming and promotes the differentiation of naive human CD4(+) T cells into high IL-4producing effectors. Blood 1998;92: 3338-3345.

30. Liu YJ, Thymic stromal lymphopoietin and OX40 ligand pathway in the initiation of dendritic cell-mediated allergic inflammation. J Allergy Clin Immunol 2007;120: 238-244; quiz 245-236.

31. Ray RJ, Furlonger C, Williams DE, Paige CJ, Characterization of thymic stromal-derived lymphopoietin (TSLP) in murine B cell development in vitro. Eur J Immunol 1996;26: 10-16.

32. Kato A, Favoreto S, Jr., Avila PC, Schleimer RP, TLR3- and Th2 cytokine-dependent production of thymic stromal lymphopoietin in human airway epithelial cells. J Immunol 2007;179: 1080-1087

33. Ito T, Wang YH, Duramad O, Hori T, Delespesse GJ, Watanabe N, Qin FX, Yao Z, Cao W, Liu YJ, TSLP-activated dendritic cells induce an inflammatory $\mathrm{T}$ helper type 2 cell response through OX40 ligand. J Exp Med 2005;202: 1213-1223.

34. Ballantyne SJ, Barlow JL, Jolin HE, Nath P, Williams AS, Chung KF, Sturton G, Wong SH, McKenzie AN, Blocking IL-25 prevents airway hyperresponsiveness in allergic asthma. J Allergy Clin Immunol 2007;120: 1324-1331.

35. Akdis M, Blaser K, Akdis CA, T regulatory cells in allergy: novel concepts in the pathogenesis, prevention, and treatment of allergic diseases. J Allergy Clin Immunol 2005;116: 961-968; quiz 969.

36. Chen Y, Kuchroo VK, Inobe J, Hafler DA, Weiner HL, Regulatory $\mathrm{T}$ cell clones induced by oral tolerance: suppression of autoimmune encephalomyelitis. Science 1994;265: 1237-1240.

37. Akdis CA, Blesken T, Akdis M, Wuthrich B, Blaser K, Role of interleukin 10 in specific immunotherapy. J Clin Invest 1998;102: 98-106.

38. Jutel M, Akdis CA, T-cell regulatory mechanisms in specific immunotherapy. Chem Immunol Allergy 2008;94: 158-177.

39. Meiler F, Klunker S, Zimmermann M, Akdis CA, Akdis M, Distinct regulation of $\mathrm{IgE}, \mathrm{IgG} 4$ and $\mathrm{IgA}$ by T regulatory cells and toll-like receptors. Allergy 2008;63: 1455-1463.

40. Verhagen J, Blaser K, Akdis CA, Akdis M, Mechanisms of allergen-specific immunotherapy: T-regulatory cells and more. Immunol Allergy Clin North Am 2006;26: 207-231, vi.

41. Cottrez F, Hurst SD, Coffman RL, Groux H, T regulatory cells 1 inhibit a Th2-specific response in vivo. J Immunol 2000;165: $4848-4853$
42. Bellinghausen I, Konig B, Bottcher I, Knop J, Saloga J, Inhibition of human allergic T-helper type 2 immune responses by induced regulatory $\mathrm{T}$ cells requires the combination of interleukin-10treated dendritic cells and transforming growth factor-beta for their induction. Clin Exp Allergy 2006;36: 1546-1555.

43. Onishi Y, Fehervari Z, Yamaguchi T, Sakaguchi S, Foxp3+ natural regulatory $\mathrm{T}$ cells preferentially form aggregates on dendritic cells in vitro and actively inhibit their maturation. Proc Natl Acad Sci U S A 2008;105: 10113-10118.

44. Gause WC, Urban JF, Linsley P, Lu P, Role of B7 signaling in the differentiation of naive CD4+ $\mathrm{T}$ cells to effector interleukin-4producing $\mathrm{T}$ helper cells. Immunol Res 1995;14: 176-188.

45. Read S, Malmstrom V, Powrie F, Cytotoxic T lymphocyteassociated antigen 4 plays an essential role in the function of $\mathrm{CD} 25(+) \mathrm{CD} 4(+)$ regulatory cells that control intestinal inflammation. J Exp Med 2000;192: 295-302.

46. Salomon B, Lenschow DJ, Rhee L, Ashourian N, Singh B, Sharpe A, Bluestone JA, B7/CD28 costimulation is essential for the homeostasis of the CD4+CD25+ immunoregulatory $\mathrm{T}$ cells that control autoimmune diabetes. Immunity 2000;12: 431-440.

47. Prasse A, Germann M, Pechkovsky DV, Markert A, Verres T, Stahl M, Melchers I, Luttmann W, Muller-Quernheim J, Zissel G, IL-10-producing monocytes differentiate to alternatively activated macrophages and are increased in atopic patients. J Allergy Clin Immunol 2007;119: 464-471.

48. Koya T, Matsuda H, Takeda K, Matsubara S, Miyahara N, Balhorn A, Dakhama A, Gelfand EW, IL-10-treated dendritic cells decrease airway hyperresponsiveness and airway inflammation in mice. J Allergy Clin Immunol 2007;119: 1241-1250.

49. Taylor A, Akdis M, Joss A, Akkoc T, Wenig R, Colonna M, Daigle I, Flory E, Blaser K, Akdis CA, IL-10 inhibits CD28 and ICOS costimulations of $\mathrm{T}$ cells via src homology 2 domaincontaining protein tyrosine phosphatase 1. J Allergy Clin Immunol 2007;120: 76-83.

50. Oh SY, Zheng T, Bailey ML, Barber DL, Schroeder JT, Kim YK, Zhu Z, Src homology 2 domain-containing inositol 5-phosphatase 1 deficiency leads to a spontaneous allergic inflammation in the murine lung. J Allergy Clin Immunol 2007;119: 123-131.

51. Ando T, Hatsushika K, Wako M, Ohba T, Koyama K, Ohnuma Y, Katoh R, Ogawa H, Okumura K, Luo J, Wyss-Coray T, Nakao A, Orally administered TGF-beta is biologically active in the intestinal mucosa and enhances oral tolerance. J Allergy Clin Immunol 2007;120: 916-923.

52. Ozdemir C, Akdis M, Akdis CA, T regulatory cells and their counterparts: masters of immune regulation. Clin Exp Allergy 2009;39: 626-639.

53. Gri G, Piconese S, Frossi B, Manfroi V, Merluzzi S, Tripodo C, Viola A, Odom S, Rivera J, Colombo MP, Pucillo CE, CD4+ $\mathrm{CD} 25+$ regulatory $\mathrm{T}$ cells suppress mast cell degranulation and allergic responses through OX40-OX40L interaction. Immunity 2008;29: 771-781.

54. Thompson-Snipes L, Dhar V, Bond MW, Mosmann TR, Moore KW, Rennick DM, Interleukin 10: a novel stimulatory factor for mast cells and their progenitors. J Exp Med 1991;173: 507510 .

55. Marshall JS, Leal-Berumen I, Nielsen L, Glibetic M, Jordana M, Interleukin (IL)-10 inhibits long-term IL-6 production but not preformed mediator release from rat peritoneal mast cells. J Clin Invest 1996;97: 1122-1128.

56. Schandene L, Alonso-Vega C, Willems F, Gerard C, Delvaux A, Velu T, Devos R, de Boer M, Goldman M, B7/CD28-dependent IL-5 production by human resting T cells is inhibited by IL-10. J Immunol 1994;152: 4368-4374.

57. Jeannin P, Lecoanet S, Delneste Y, Gauchat JF, Bonnefoy JY, IgE versus IgG4 production can be differentially regulated by IL-10. J Immunol 1998;160: 3555-3561. 
58. Satoguina JS, Adjobimey T, Arndts K, Hoch J, Oldenburg J, Layland LE, Hoerauf A, Tr1 and naturally occurring regulatory $\mathrm{T}$ cells induce IgG4 in B cells through GITR/GITR-L interaction, IL-10 and TGF-beta. Eur J Immunol 2008;38: 3101-3113.

59. Akdis $M$, Healthy immune response to allergens: $T$ regulatory cells and more. Curr Opin Immunol 2006;18: 738-744.

60. Ling EM, Smith T, Nguyen XD, Pridgeon C, Dallman M, Arbery J, Carr VA, Robinson DS, Relation of CD4+CD25+ regulatory T-cell suppression of allergen-driven T-cell activation to atopic status and expression of allergic disease. Lancet 2004;363: 608-615.

61. Sakaguchi S, Yamaguchi T, Nomura T, Ono M, Regulatory T cells and immune tolerance. Cell 2008;133: 775-787.

62. Francis JN, Till SJ, Durham SR, Induction of IL-10+CD4+CD25+ $\mathrm{T}$ cells by grass pollen immunotherapy. $\mathrm{J}$ Allergy Clin Immunol 2003;111: 1255-1261.

63. Jutel M, Akdis M, Budak F, Aebischer-Casaulta C, Wrzyszcz M, Blaser K, Akdis CA, IL-10 and TGF-beta cooperate in the regulatory $\mathrm{T}$ cell response to mucosal allergens in normal immunity and specific immunotherapy. Eur J Immunol 2003;33: 1205-1214.

64. Jutel M, Pichler WJ, Skrbic D, Urwyler A, Dahinden C, Muller UR, Bee venom immunotherapy results in decrease of IL-4 and IL-5 and increase of IFN-gamma secretion in specific allergenstimulated T cell cultures. J Immunol 1995;154: 4187-4194.

65. Nouri-Aria KT, Wachholz PA, Francis JN, Jacobson MR, Walker SM, Wilcock LK, Staple SQ, Aalberse RC, Till SJ, Durham SR, Grass pollen immunotherapy induces mucosal and peripheral IL10 responses and blocking $\operatorname{IgG}$ activity. J Immunol 2004;172: 3252-3259.

66. Pilette C, Nouri-Aria KT, Jacobson MR, Wilcock LK, Detry B, Walker SM, Francis JN, Durham SR, Grass pollen immunotherapy induces an allergen-specific IgA2 antibody response associated with mucosal TGF-beta expression. J Immunol 2007;178: 4658-4666.

67. Varney VA, Hamid QA, Gaga M, Ying S, Jacobson M, Frew AJ, Kay AB, Durham SR, Influence of grass pollen immunotherapy on cellular infiltration and cytokine mRNA expression during allergen-induced late-phase cutaneous responses. J Clin Invest 1993;92: 644-651.

68. Radulovic S, Jacobson MR, Durham SR, Nouri-Aria KT, Grass pollen immunotherapy induces Foxp3-expressing CD4+ CD25+ cells in the nasal mucosa. J Allergy Clin Immunol 2008;121: 1467-1472, 1472 e1461.

69. Jutel M, Jaeger L, Suck R, Meyer H, Fiebig H, Cromwell O, Allergen-specific immunotherapy with recombinant grass pollen allergens. J Allergy Clin Immunol 2005;116: 608-613.

70. van der Giessen M, Homan WL, van Kernbeek G, Aalberse RC, Dieges PH, Subclass typing of IgG antibodies formed by grass pollen-allergic patients during immunotherapy. Int Arch Allergy Appl Immunol 1976;50: 625-640.
71. Bettelli E, Carrier Y, Gao W, Korn T, Strom TB, Oukka M, Weiner HL, Kuchroo VK, Reciprocal developmental pathways for the generation of pathogenic effector TH17 and regulatory T cells. Nature 2006;441: 235-238.

72. Weaver CT, Harrington LE, Mangan PR, Gavrieli M, Murphy KM, Th17: an effector CD4 T cell lineage with regulatory $\mathrm{T}$ cell ties. Immunity 2006;24: 677-688.

73. Harrington LE, Hatton RD, Mangan PR, Turner H, Murphy TL, Murphy KM, Weaver CT, Interleukin 17-producing CD4+ effector $\mathrm{T}$ cells develop via a lineage distinct from the T helper type 1 and 2 lineages. Nat Immunol 2005;6: 1123-1132.

74. Mangan PR, Harrington LE, O'Quinn DB, Helms WS, Bullard DC, Elson CO, Hatton RD, Wahl SM, Schoeb TR, Weaver CT, Transforming growth factor-beta induces development of the $\mathrm{T}(\mathrm{H})$ 17 lineage. Nature 2006;441: 231-234.

75. Bettelli E, Korn T, Oukka M, Kuchroo VK, Induction and effector functions of $\mathrm{T}(\mathrm{H}) 17$ cells. Nature 2008;453: 1051-1057.

76. Hellings PW, Kasran A, Liu Z, Vandekerckhove P, Wuyts A, Overbergh L, Mathieu C, Ceuppens JL, Interleukin-17 orchestrates the granulocyte influx into airways after allergen inhalation in a mouse model of allergic asthma. Am J Respir Cell Mol Biol 2003;28: 42-50.

77. Sergejeva S, Ivanov S, Lotvall J, Linden A, Interleukin-17 as a recruitment and survival factor for airway macrophages in allergic airway inflammation. Am J Respir Cell Mol Biol 2005;33: 248253.

78. Dong C, Regulation and pro-inflammatory function of interleukin17 family cytokines. Immunol Rev 2008;226: 80-86.

79. Fort MM, Cheung J, Yen D, Li J, Zurawski SM, Lo S, Menon S, Clifford T, Hunte B, Lesley R, Muchamuel T, Hurst SD, Zurawski G, Leach MW, Gorman DM, Rennick DM, IL-25 induces IL-4, IL-5, and IL-13 and Th2-associated pathologies in vivo. Immunity 2001;15: 985-995.

80. Hurst SD, Muchamuel T, Gorman DM, Gilbert JM, Clifford T, Kwan S, Menon S, Seymour B, Jackson C, Kung TT, Brieland JK, Zurawski SM, Chapman RW, Zurawski G, Coffman RL, New IL-17 family members promote Th1 or Th2 responses in the lung: in vivo function of the novel cytokine IL-25. J Immunol 2002;169: 443-453.

81. Elyaman W, Bradshaw EM, Uyttenhove C, Dardalhon V, Awasthi A, Imitola J, Bettelli E, Oukka M, van Snick J, Renauld JC, Kuchroo VK, Khoury SJ, IL-9 induces differentiation of TH17 cells and enhances function of FoxP3+ natural regulatory $\mathrm{T}$ cells. Proc Natl Acad Sci U S A 2009;106: 12885-12890.

82. Nograles KE, Zaba LC, Shemer A, Fuentes-Duculan J, Cardinale I, Kikuchi T, Ramon M, Bergman R, Krueger JG, GuttmanYassky E, IL-22-producing "T22" T cells account for upregulated IL-22 in atopic dermatitis despite reduced IL-17-producing TH17 T cells. J Allergy Clin Immunol 2009;123: 1244-1252.e1242. 